\title{
GET: A STUDY OF ITS DEEP MEANINGS.
}

I. When one opens a dictionary to look up the meaning of get one will probably be amazed at the number of different entries and therefore "meanings" of this verb. Hornby, for example, in his The Advanced Learner's Dictionary of Current English lists 18 different meanings for it, besides a special entry for its occurrence with prepositions and /or adverbials, in which he has 41 entries, almost all of them having several different meanings.

Thepurpose of this paper is to study the possibility of putting together, on a syntactic basis, some of these "different meanings" in an attempt to arrive at as few meanings as possible for get. By "meanings", one should understand underlying meanings or, let us call them, deep meanings. As a first step we shall examine some traditional approaches to the problem.

II. In a traditional approach the authors tend to list the different surface meanings of get without hardly any effort of grouping similar meanings together. Heaton (1970) first mentions that get is a substitute for certain verbs: When does the train get to London? (= arrive) Next he offers other meanings:

- obtain: I got a pound of meat from the butcher.

- receive: Did you get the letter I wrote?

- fetch: Get me a few pencils.

- acquire: The little boy had got the old coin from a rich uncle.

Finally he refers to the phrase have got stating that it is synonymous to have. (1)

(1) - It is worth mentioning here that American English has a further form have gotten, with a distinct meaning. Marckwardt (1958) provides the following examples: " 'We' ve got ten thousand dollars for laboratory equipment,' means that the funds in question are in our possession - we have them. 'We have gotten ten thousand dollars for laboratory equipment,' means that we have obtained or acquiced this particular sum of money (p. 75-76)." However, we shall not deal with this distinction as it is beyond the scope of this paper. 
Based purely on intuition it would probably be possible to state that obtain, receive, fetch and acquire have something in common, that they have an underlying common meaning. However, we shall proceed before attempting any premature classification at this point.

Hopper (1970) mentions the meaning of become: The patient is feeling better and will soon get well. This meaning is not mentioned by Heaton and, as far as one can see, it does not share a common meaning with those alternatives presented by Heaton. A semantic criterion would corroborate a two-group division:

$\begin{array}{lll}\text { Group } & \text { Meaning } & \text { Example } \\ \text { I } & \begin{array}{l}\text { obtain, receive, fetch, } \\ \text { acquire }\end{array} & \text { He got a book } \\ \text { II } & \text { become } & \text { He got well }\end{array}$

A third author, McMordie (1972) proposes the following list of meanbination either with prepositions or adverbials. Reference will be made to them in a later part of this paper.

A third author, McMordie (1972) proposes the following list of meaings for the simple verb get:

- procure, obtain, acquire, come into possession: You cannot get admission here.

- receive (without implying effort): get a fever, get measles.

- prevail upon, induce, persuade: The have got my father to contribute.

- cause to be, to have: Get these books sent off

- learn, commit to memory; get by heart: He has to get fifty lines of poetry by heart.

- bring into a state or place: I got the chest down to my raft.

- bring oneself into a state or condition, to become or come to be: They have got safe to land. I got acquainted with the captain of the ship. The fence was so strong that nothing could get inside or over it.

- become, gradually coming or going into a condition: They got rich suddenly (Defoe).

It is worth noticing that in some of the Author's examples what actually occurs is not the simple verb (as he wants it) but get in some kind of combination, that is, get followed either by an adverb or by a prepositional phrase: get by heart, get down, inside, get over. As our attempt is to arrive at the underlying meanings of the simple 
verb, these combinations will be excluded from our analysis for the time being.

Besides, his one group before last is to be questioned, namely the one having the meaning of "bringing oneself into a state or condition" included together with "to become or come to be". They got safe to land does not seem to fit in there at all. Rather, it appears to express movement somehow, as we could paraphrase it as We arrived safe on land. So, apparently, there is a third group.

We shall now try to distribute McMordie's proposed meanings among our groups:

$\begin{array}{ll}\text { Group } & \text { Meaning } \\ \text { I } & \begin{array}{l}\text { Ebtain, receive, fetch, acquire, He got a book. } \\ \text { procure, acquire, come into pos- } \\ \text { session, receive (without im- } \\ \text { plying effort) }\end{array} \\ \text { II } & \begin{array}{l}\text { become; become or come to be; He got well. } \\ \text { become, gradually coming or } \\ \text { going into a condition } \\ \text { III } \\ \text { bring oneself into a state or They got safe to land. } \\ \text { condition }\end{array}\end{array}$

It can also be noticed that a fourth group has to be created to account for prevail upon, induce, persuade, and cause to be, to have, which seem to share a common meaning. For the time being this will be:

$\begin{array}{lll}\text { Group } & \text { Meaning } & \text { Example } \\ \text { IV } & \begin{array}{l}\text { prevail upon, induce, persuade; } ; \\ \text { cause to be, to have }\end{array} & \begin{array}{l}\text { They have got my father to con- } \\ \text { tribute. }\end{array}\end{array}$

III. A structural approach to the study of get will provide us with the structures in which it occurs. Christophersen (1969) states that get occurs as
- a linking verb: We got wet.
- a catenative followed by ing or past participle: We'd better get going. The bottle got broken.
- a catenative with intervening nominal: I got him to do it.

So, get as a linking verb would fit into our group II; as a catenative followed by -ing, into our group III and as a catenative with inter- 
vening nominal, into our group IV We are not able to place get as a catenative followed by a past participle, but it can easily be noted that this is an occurrence of a passive structure, which is beyond the scope of this paper. Also, Christophersen does not provide a structure for the occurrence of our group I get.

The first work that will really contribute towards a semantic classification of get is Palmer's (1974) In his book the Author combines a structural approach with a semantic analysis. This is actually the first attempt to group verbs together both on a semantic and a formal basis. Concerning get he first states that it may be used as "an alternative to $\mathrm{BE}$ in the formation of the passive: He was killed by the bus. He got killed by the bus." (2) (p. 89) He makes it clear, however, that in this case get is not a linking verb and, therefore, cannot "substitute with BE in the statal passive type - but in the normal passive. (3) However, semantically, forms with GET have much in common with statal passives. GET always suggests that the person or object designated by the subject NP has undergone some change or has been in some way affected - with lasting effect. ( ) Semantically, GET reports both the action and the resultant state. The ball got lost says both The ball was lost (passive) and The ball was lost (statal passive). It can thus be seen either as a process verb with an -en form while BE is purely statal, or as combining the two functions of $\mathrm{BE} "$ (p. 89)"

When Palmer states that get always suggests a change undergone by the subject, he is actually referring to our group II: He got well.

Next he gives the classification of catenative verbs and in one of its items he deals with homonyms, stating that "a verb that seems to have several homonyms is GET" He provides the following examples with their corresponding meanings:

- I got to see that I was wrong ( = I eventually saw that. )

- I got them to see that they were wrong. ( = I caused them to see...)

- I got working hard at the project. ( = a process verb

- I got them working hard at the project. like KEEP)

- I got hurt in the crash. (= I was hurt in the crash.)

(cf. p. 194)

(2) - Although occurrences of get in passive structures will not be dealt with in this paper, Palmer's analysis of this point will be mentioned as it appears to confirm our previous idea that group III implies a meaning of movement or process.

(3) - The ball was lost (A bola estava perdida) (statal passive) $={ }^{*}$ The ball got lost. lost.

The ball was lost (A bola foi perdida) (normal passive) $=$ The ball got 
Before commenting on the above example, let us complete the reference to Palmer's study, mentioning the catenative classes in which get appears, based on a semantic approach:

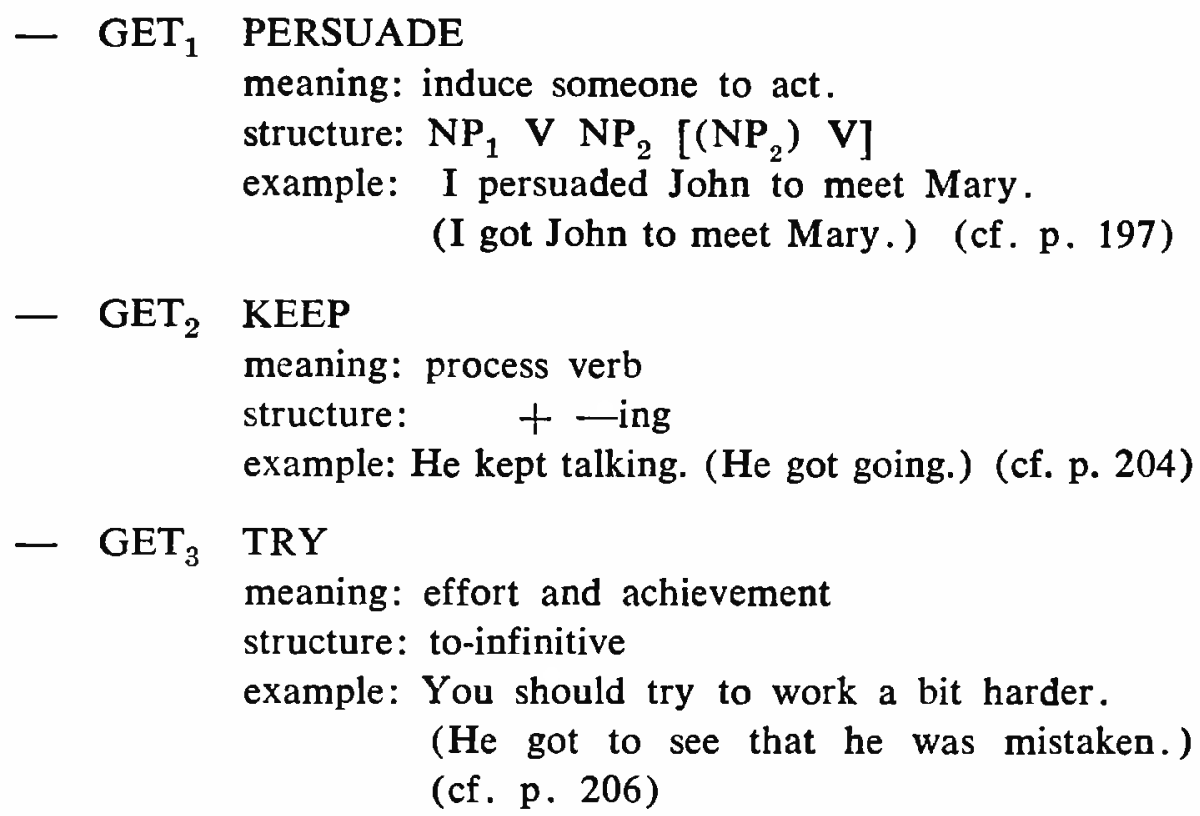

Let us analyze each one of these classes. The classification of $\mathrm{GET}_{1}$ is almost satisfactory, except that it does not always mean "induce someone to act" as can be seen from Palmer's own example I got them to see that they were wrong, although he claims that here get has the meaning of cause to. The structure, however, is the same. Notice that I got John to meet Mary can very well be paraphrased as I caused John to meet Mary. This proves that both cause and persuade belong to the same group, namely group IV

As for $\mathrm{GET}_{2}$, it must be made clear that, although it is a process verb, it cannot be considered synonymous to KEEP, as the latter implies the continuance of an action, whereas get implies the beginning of an action: He got going (= He began the action of going.) The same applies to $I$ got working hard at the project ( = I began working hard at the project.) Thus referring to get as a process verb, Palmer offered the following example: I got them working hard at the project. We hope this has been a misprint, as it is clearly an instance of $\mathrm{GET}_{1}$. $\mathrm{GET}_{3}$ is also a process verb, the difference being, as opposed to GET ${ }_{2}$, that it indicates the result of the process; that is why Palmer claims it to have the meaning of "effort and achievement."

The chart below is a summary of our data up to this point: 
Palmer

\begin{tabular}{|c|c|c|c|c|c|}
\hline Group & $\begin{array}{l}\text { Traditional } \\
\text { Approach }\end{array}$ & $\begin{array}{l}\text { Christopher- } \\
\text { sen } \\
\text { (structural) }\end{array}$ & (semantic) & (structural) & Example \\
\hline I & obtain, etc. & no reference & no refer. & no reference & $\begin{array}{l}\text { He got a } \\
\text { book. }\end{array}$ \\
\hline II & become, etc. & linking verb & change & $+\mathrm{ADJ}$ & He got rich. \\
\hline III & $\begin{array}{l}\text { bring one- } \\
\text { self into } \\
\text { condition or } \\
\text { state }\end{array}$ & $\begin{array}{l}\text { catenative } \\
+ \text {-ing }\end{array}$ & process & $\begin{array}{l}\text { caten. + } \\
\text {-ing } \\
\text { caten. + } \\
\text { to-inf. }\end{array}$ & $\begin{array}{l}\text { He got wor- } \\
\text { king. } \\
\text { I got to see... }\end{array}$ \\
\hline $\mathrm{V}$ & $\begin{array}{l}\text { prevail, } \\
\text { upon, etc. }\end{array}$ & $\begin{array}{l}\text { catenative } \\
\text { ing nominal }\end{array}$ & $\begin{array}{l}\text { persuade } \\
\text { cause } \\
\text { w/ interven- }\end{array}$ & $\begin{array}{l}\mathrm{NP}_{1} \mathrm{VNP}_{2} \\
{\left[\left(\mathrm{NP}_{2}\right) \mathrm{V}\right]}\end{array}$ & $\begin{array}{l}\text { I got them to } \\
\text { see. }\end{array}$ \\
\hline
\end{tabular}

IV For our final analysis we shall follow two models. One is Fillmore's case grammar presented in his "Case for Case" (1968) and reviewed in "Some Problems for Case Grammar" (1971) and the other one is Lakoff's classification of inchoative and causative verbs.

Let us first turn to Fillmore. It must be made clear that his case grammar deals with the deep structure of sentences and that when he mentions case relationships or case categories, they are always to be interpreted at a deep structure level.

Fillmore proposes a radical change in the Phrase Structure (PS) rules known to date. For him the basic structure of a sentence is made up of "a verb and one or more noun phrases, each associated with the verb in a particular relationship. (p. 21) "This relationship he calls case relationship and he also claims that each one of these "occurs only once in a simple sentence (p. 21) "In his 1971 paper he will call the latter the "one-instance-per-clause" principle. (1971), p. 38). In other words, a sentence consists of a 'proposition' and a 'modality' constituent. The latter "will include such modalities on the sentenceas-a-whole as negation, tense, mood, and aspect" but Fillmore does not go into that part in detail. He concentrates on the 'proposition' constituent which is a "tenseless set of relationships involving verbs and nouns (and embedded sentences, if there are any)" (4) The 'proposition' is expanded as a verb and a set of case relationships,

(4) - We have omitted the part which refers to the rewriting of the PS rules as they are not relavant to the analysis intended. 
"where at least one case category must be chosen and where no category appears more than once (p. 24)"

In order to define his notions on case, Fillmore states that they "comprise a set of universal, presumably innate, concepts which identify certain types of judgements human beings are capable of making about the events that are going on around them, judgements about such matters as who did it, who it happened to, and what got changed ( $p$. 24)

Out of his universal array of cases, Fillmore selects the ones he believes to apply to the English language. However, only those which interest us more directly shall be mentioned below:

- "Agentive (A), the case of the typically animate perceived instigator of the action defined by the verb.

- Instrumental (I), the case of the inanimate force or object causally involved in the action or state identified by the verb.

- Dative (D) the case of the animate being affected by the state or action identified by the verb.

- Locative (L), the case which identifies the location or spatial orientation of the state or action identified by the verb.

- Objective $(0)$, the semantically most neutral case, the case of anything representable by a noun whose role in the action or state identified by the verb is identified by the semantic interpretation of the verb itself; conceivably the concept should be limited to things which are affected by the action or state identified by the verb. The term is not to be confused with the notion of direct object, nor with the name of the surface case synonymous with accusative." (p. 24-25) "

He then gives examples to show that the selection of the surface structure subject does not change its deep structure case relationship to the verb. John is A in 1, 2, 4, and 5; the door is $\mathrm{O}$ in all of them; the key is $I$ in 3, 4 as well as 5 .

1. John opened the door.

2. The door was opened by John.

3. The key opened the door.

4. John opened the door with the key.

5. John used the key to open the door.

In all three sentences below, despite their surface structure differences, John is D

6. John believed that he would win.

7 We persuaded John that we would win.

8. It was apparent to John that we would win. (cf. p. 25). 
Next Fillmore introduces two new concepts: 'case frame' and 'frame features' The 'case frame' is the "array of cases ( ) provided by the sentence." The selection of the verbs depends on this "case frame' So, the verb run may be inserted in the case frame

[- A] as in John runs (5), the verb sad (6) into the frame [- D] as in John is sad, the verb give into the frame $[-\mathrm{O}+\mathrm{D}+\mathrm{A}]$ as in John gave Peter a book.

Going back to the verb open we see that it can occur in several case frames:

9. The door opened: [-

10. John opened the door: $[-\mathrm{O}+\mathrm{A}]$

11. The wind opened the door: $[-\mathrm{O}+\mathrm{I}]$

12. John opened the door with a chisel: $[-\mathrm{O}+\mathrm{I}+\mathrm{A}]$

In the lexical entry for open then, all case frames would have to be stated. This combination would then form the verb's 'frame features', that is, "the set of case frames into which the given verbs may be inserted." In order to simplify the representation of this set of possibilities, parentheses are used to indicate optional elements.

So, the frame feature for open may be represented as:

$$
\text { 13. }+[-O \text { (I) (A) }] \text { (7) }
$$

A verb like kill may occur in the following examples:

14. Peter killed John: $[\longrightarrow-D+A]$

15. Peter killed John with a knife: $[-D+I+A]$

16. A knife killed John: [- $-\mathrm{D}+\mathrm{I}]$

Fillmore introduces the notation of linked parentheses "to indicate that at least one of the linked elements must be chosen" (p. 28) and gives the following frame feature for kill

$$
17+[\longrightarrow \text { (I ) ( A)] }
$$

The verb murder, on the other hand, requires an Agentive to be obligatorily present. Its frame feature is

$$
\text { 18. }+[\longrightarrow \text { D (I) A }]
$$

(5) - These examples have been provided by us.

(6) - In Note 36 Fillmore states that he is "adhering ( . . ) to the PostalLakoff doctrine (...) that adjectives constitute a subset of verbs." (p. 27).

(7) - (Note 37): "Case frames are represented in square brackets, with 'underline' indicating the position of the element with respect to which the expression is an environmental frame (p. 27)." 
Fillmore accounts for embedded sentences as an $\mathrm{O}$ to which an St (Sentence) (8) has been embedded. He provides the following examples of frame features with embedded sentences:

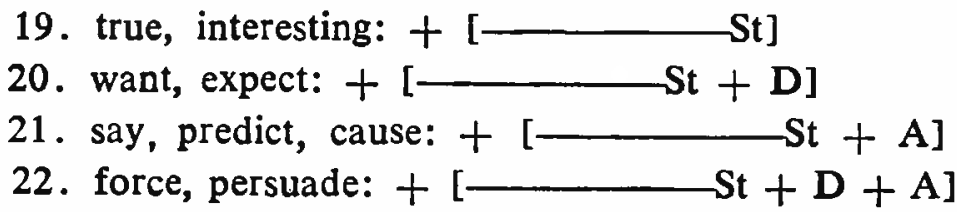

In 1971 Fillmore published "Some Problems for Case Grammar", in which he reviews his previous array of cases and comes up with the followin modifications:

a.he gets rid of the Dative and creates an Experiencer (E), which will represent the experiencer of a psychological or mental event: $\mathrm{He}$ imagined an accident;

b.the Instrumental, besides indicating the immediate cause of an event, also represent the psychological stimulus or reactedto situation in a mental event: The noise frightened me; an event, also represents the psychological stimulus or reacted. change;" it is also teh content of a psychological experience: The noie reminded me of the accident;

d.he creates two new cases, namely Source (S) and Goal (G), to indicate, respectively, the earlier and later locations, states or time points. Goal also expresses "the receiver as destination" and an "end result of some action or change": The ball went over the fence;

e.Path is another new case for instances like: He walked from the cemetery gate to the chapel along the canal. It is represented by $P$

The case which remains unchanged is Agentive, the instigator of the action, the principal cause of the event, as opposed to the immediate cause represented by the Instrumental.

The chart below presents the frame features for our four gromps based on Fillmore's 1968 and 1971. Besides, the list of meanings in each group has been simplified in that one term has been chosen to account for all meanings in that group.

(8) - We have chosen to use $S t$ for Sentence in the frames, as further on $S$ will stand for Source. 

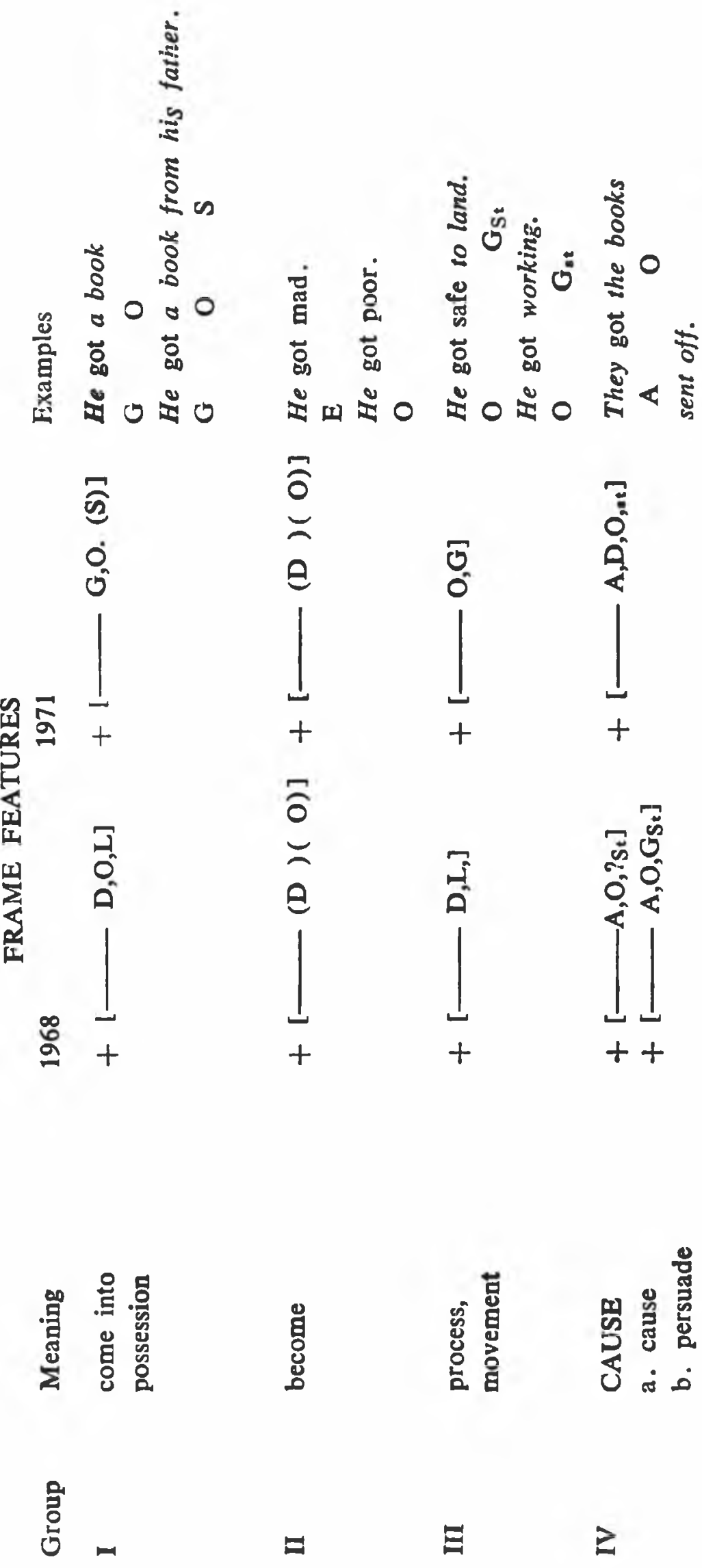
In the above frame features, the leftmost case is the one that usually surfaces as the subject. So, we can see that in the 1968 model three out of the four groups had a Dative in subject position. This was so because this case was a very broad one. In 1971 Fillmore distributes the relationships of the nouns to the verbs represented by the Dative among other cases, thus making the distinction among the cases much clearer. As far as our groups are concerned, the differences are much more evident: when get is a full verb, meaning come into possession, the subject position is occupied by a Goal; when it means become, the subject may be either an Experiencer or an Objective; in the case of get as a verb indicating movement, the subject is an Objective.

Another aspect in favor of the 1971 model relates to the last group, insofar as it makes it possible to group together the meanings of cause and persuade under a more general heading CAUSE. The 1968 model does not permit an acceptable analksis of They got the book sent off, as one would have to posit the Objective case twice, once for the books and once for the embedded sentence implied by sent off It will be remembered that this goes against Fillmore's "one-instance-per-clause" principle mentioned previously. Also, in the 1968 model, all sentences were embedded in the Objective case, whereas in the 1971 model embedded sentences can be of any case.

$\mathrm{V} \quad \mathrm{Up}$ to now we have not made use of any transformations and we shall mention them just in passing as we refer to Lakoff (1970) With reference to our subject, he proposes two minor (9) transformational rules which he calls inchoative and causative.

The inchoative rule applies on inchoative verbs, that is, verbs which denote a change of state, such as become. for example, in The sauce became thick. From our analysis up to this point this sentence can be paraphrased as The sauce got thick, for which Lakoff posits the following deep structure:

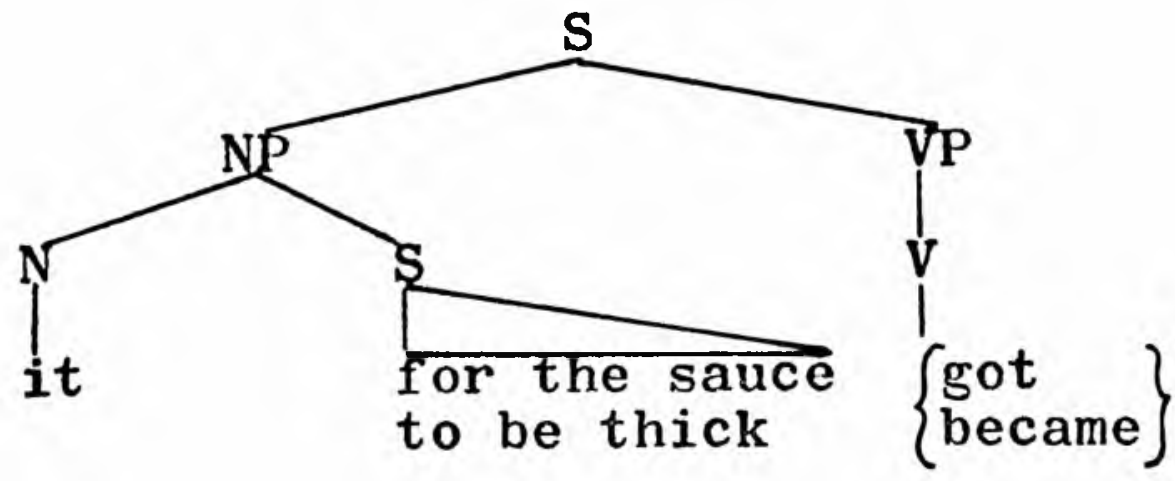

(9) - Minor rules are rules "that apply only to exceptions" (Lakoff, 1970 p. 30). 
It can easily be seen that this occurrence of get fits into our group III (become)

After working through Extraposition

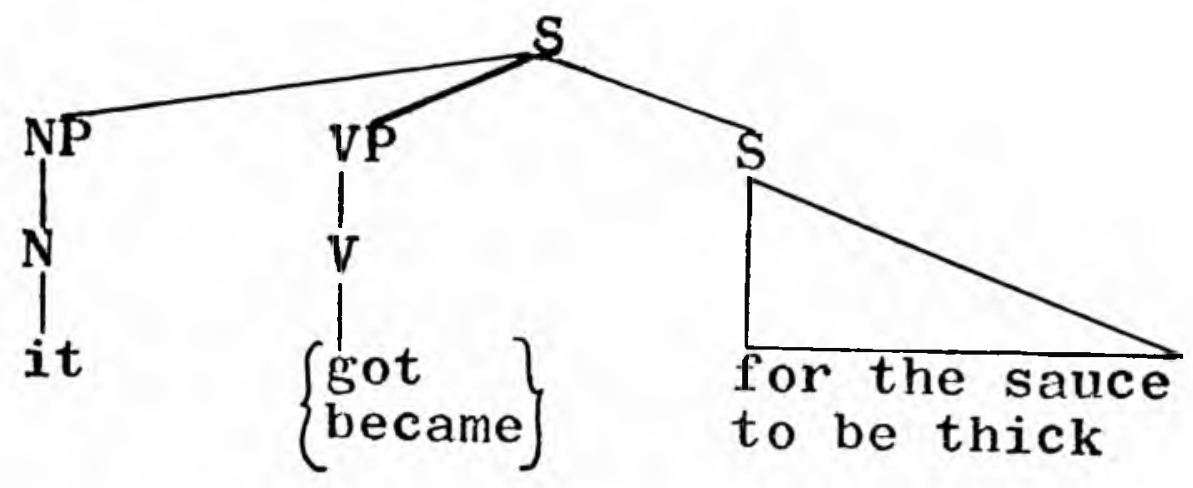

It-substitution

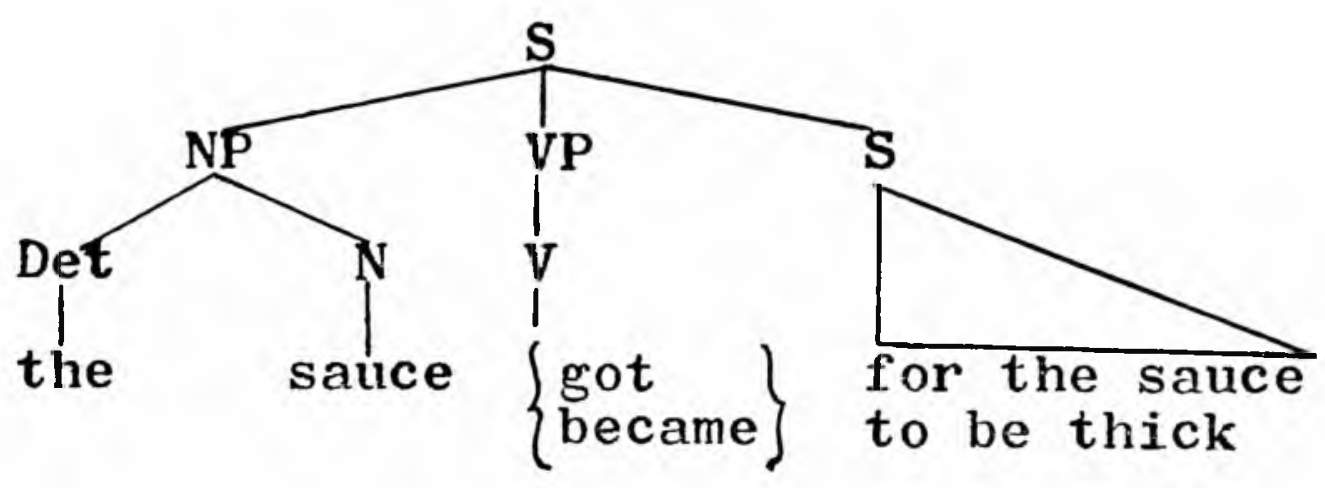

Identical Noun Phrase Deletion

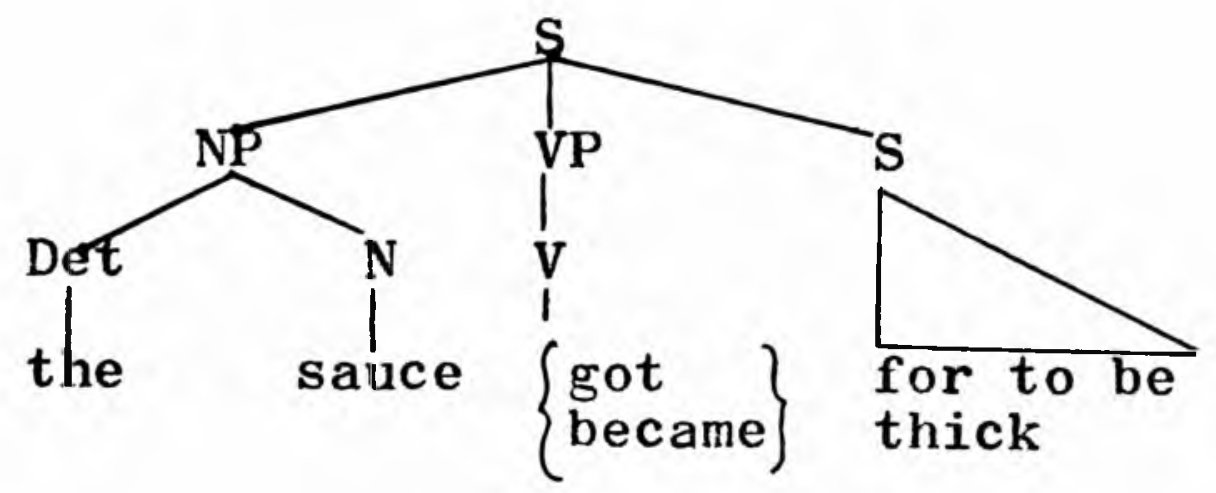




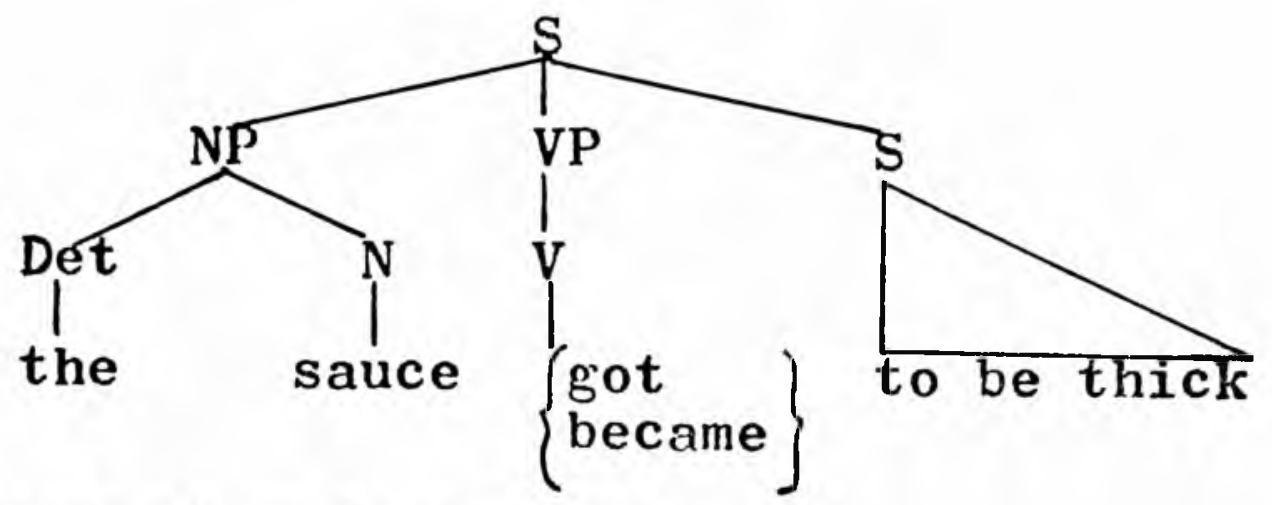

and to be deletion, he arrives at

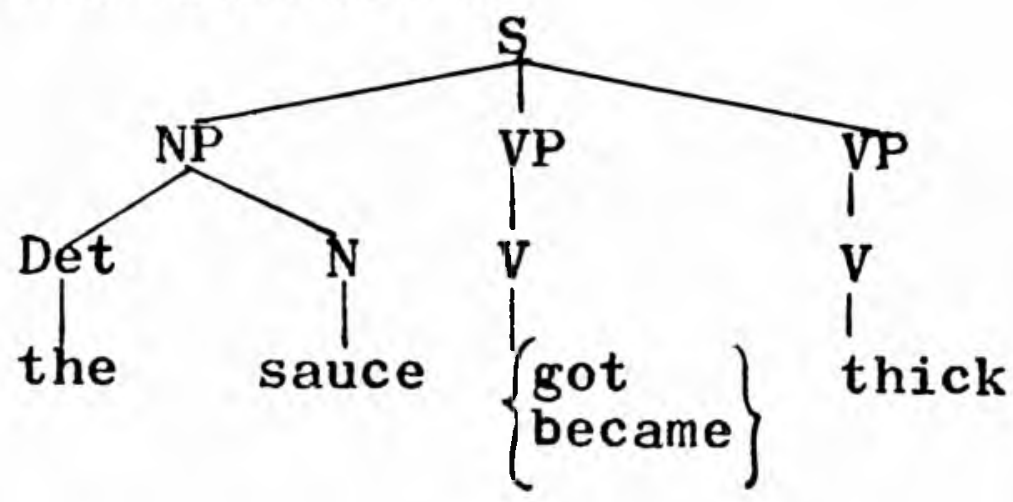

If we apply Fillmore's cases to this inchoative structure, we will realize that the sauce stands for the Objective (the entity that undergoes change) and that thick is actually a verb (see Note 6) So, we will have the frame [- O], thus confirming our previous analysis for get when meaning become. In other words, the become group (group II) represents the inchoative get.

As for the causative rule, Lakoff states that it "operates on inchoative verbs - usually on the product of the inchoative rule (p. 43) " Here is an example with a causative verb John got the sauce to thichen (= John caused the saused to thicken), for which we have the following deep structure:

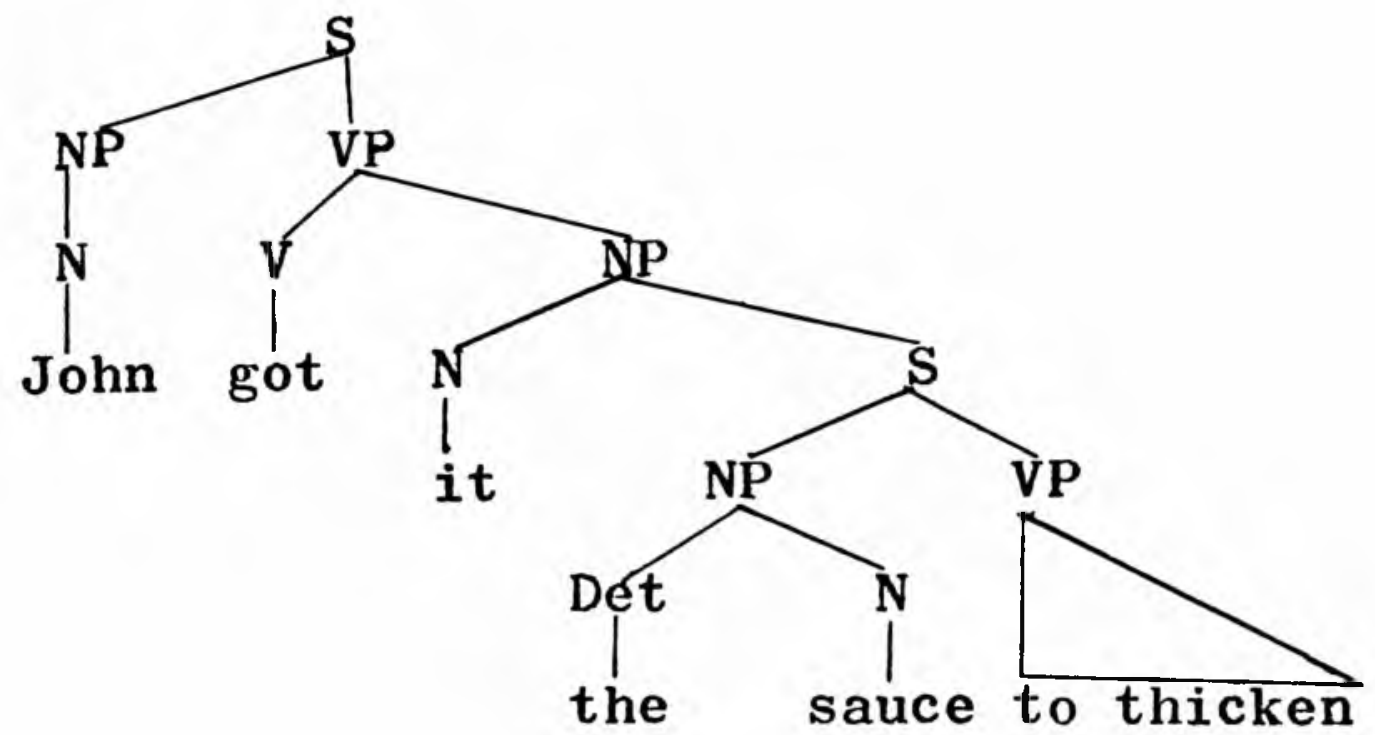


Applying Fillmore's case grammar to this structure we would have: John as the Agentive, it as the Objective, the sauce as the Objective of the embedded sentence and the whole embedded sentence as the Goal of the matrix. Again, this ratifies our previous frame for get withthe meaning of CAUSE +- [— A,O,G,S $]$, which we will now call causative.

At this point we are in a position to draw the following summary:

\begin{tabular}{|c|c|c|c|}
\hline Gioup & Meaning & Lakoff's cassification & $\begin{array}{c}\text { Fillmore's Frame } \\
\text { Feature }\end{array}$ \\
\hline I & $\begin{array}{l}\text { come into } \\
\text { possession }\end{array}$ & no refecence is made & $+[-G, O(S)]$ \\
\hline II & $\begin{array}{l}\text { become } \\
\text { change of } \\
\text { state }\end{array}$ & Inchoative & $+[-(E)(0)]$ \\
\hline III & $\begin{array}{l}\text { process } \\
\text { movement }\end{array}$ & no reference is made & $+[-0, G]$ \\
\hline IV & $\begin{array}{l}\text { CAUSE } \\
\text { b. persuade } \\
\text { a. cause }\end{array}$ & causative & $+\left[-\mathrm{A}, \mathrm{O}, \mathrm{G}_{\mathrm{S}}\right]$ \\
\hline
\end{tabular}

The chart shows us that the evidence presented, based on Filmmore and Lakoff, has served to prove that the four groups, initially distinguished on an intuitive basis, actually correspond to four distinct verbs get:
a. get as a full verb, meaning come into possession, whose frame feature is $+[-G, O(S)]$;
b. get as an inchoative verb, indicating change of state and having the frame feature $+[-(E)(O)]$;
c. get as a verb of movement, with the frame feature $+[-0, G]$
d. and get as acausative verb, with the frame feature $+\left[-\mathrm{A}, \mathrm{O}, \mathrm{G}_{\mathrm{st}}\right]$.

VI. We shall now test our corpus, taken from the Oxford Dictionary of Current Idiomatic English, volume 1: Verbs with Prepositions and Particles, to see if get, when occurring in combination with prepositions and particles is also subject to this classification.

We have collected 233 different entries. This does not mean that get occurs with 233 different prepositions or particles, but that it occurs with prepositions and particles in 233 different meanings. For 
example, the cobinition get + about occurs with twodifferent meanings: get + at with six different meanings, get + out with twenty seven different meanings. Each meaning has its distinct frame feature.

\section{Findings}

a. We have come across no examples of either the inchoative or the causative structures;

b. out of the 233 entries for get in cobination with prepositions and particles, only 15 belonged to the group I ( $+[-\mathrm{G}, \mathrm{O}(\mathrm{S})])$, namely the group of get as a full verb, and these referred to;

get + back: 'Don't lend Bill your umbrella! If you do, you'll never get it back

G

\section{O S}

get + out: In most walks of life you only get out what you put in

$(\ldots)$

G $\quad S \quad \mathrm{O}_{\mathrm{st}}$

get $+\mathrm{NP}+$ of: 'Don't always try and get the better of her over

every stupid incident.

c. all 218 remaining entries belonged to group III, get as a verb of movement.

c. 1 In 144 out of these 218 entries, the preposition or particle represents the Goal and appears in the following frames:

[—_ O $\mathrm{O}$ G] (75 entries)

The news got abroad that the Chancellor had decided ...

$\mathrm{O}$

G

[- $\mathrm{A}+\mathrm{O}+\mathrm{G}]$ (52 entries)

He took the spring out of the clock, but now he can't get it back.
A
O G

$[-\mathrm{O}+\mathrm{G}+\mathrm{S}]$ (12 entries)

I got up from the table and left the room.

O $\mathbf{G} \quad \mathbf{S}$

[- $\mathrm{I}+\mathrm{O}+\mathrm{G}]$ (5 entries)

His insolent manner got my blood up...

I

O G

c.2 In 58 entries the particles and prepositions represent the Path and they appear in the following frames: 
[- O+ P] (38 entries)

The frontier is so well guarded that

no one can get across.

O P

$[-\mathrm{A}+\mathrm{O}+\mathrm{P}]$ (10 entries)

We got the children safely over the fence...

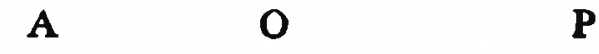

$[-\mathrm{O}+\mathrm{P}+\mathrm{G}]$ (7 entries)

I hope you don't mind if we get down to business...

$\mathbf{P} \quad \mathbf{G}$
0

$[-\mathbf{A}+\mathbf{O}+\mathbf{P}(\mathbf{G})]$ (3 entries)

The comedian didn't (...) get his jokes across to his audience...

$\begin{array}{lllll}\text { A } & \text { O } & \text { P } & \text { G }\end{array}$

c. 3 There are 21 occurrences of prepositions and particles as Source in the following frames:

$[-\mathrm{O}+\mathrm{S}+\mathrm{G}]$ (7 entries)

The runners got off to a flying start.

O S G

$[-\mathrm{O}+\mathrm{S}]$ (8 entries)

The children were told to get off the scaffolding...

$\mathrm{O}$

$\mathbf{S}$

$[-\mathrm{A}+\mathrm{O}+\mathrm{S}]$ (6 entries)

The lawyer got the client off with a fine of five pounds.

A $\quad 0 \quad S$

d. What is important about all this information is that the prepositions and particles that occur with get are always instances of one of three cases: Goal, Source or Path, all of them indicating movement. It ought to be noticed that Location does not occur, as Fillmore states that it is either an "optional complement of essentially any predicator" or that the "events or situations which can be located in space and time are themselves to be embedded into higher sentences containing as their main verb something like occur or happen with the understanding that it is this higher verb which takes Location-and-Time introducing cases. (p. 49)"

\section{Conclusions}

Our final step is to revise our frames for the different groups based on the corpus analysed. As it offered no examples of the inchoative and causative verbs get, these frames will remain unchanged.

Our frame for group I (come into possession) has been confirmed by the examples from the corpus (get + back, get + out, and get $+\mathrm{NP}+$ of), the only difference being that $S$ is obligatory in 
these instances as it is represented by the preposition or particle. When get does not occur in combination with these words, $\mathrm{S}$ is optional in the surface structure, although we believe it is obligatory in the deep structure and then deleted by a later transformation.

As far as our group III (movement) is concerned, we will have to enlarge our frame so as to account for the occurrences of Path and Source, which had not occurred in our previous examples. So, our revised frame will be $+[-O(G)$ (P) (S) $]$, which is broad enough to account for all instances.

We believe that in this way we have shown that:

I. it is possible to classify the wide range of different meanings of the verb get, presented in a traditional way, both for the verb in isolation as in combination with prepositions or particles, into four groups;

2. Christophersen's classification is not complete as he does not mention get as a full verb;

3. Palmer's classification is not complete for the same reason. Besides, his classes are not very clearly outlined;

4. Fillmore's 1971 model provided the best theoretical support for the classification arrived at;

5 Lakoff confirmed two of the groups, providing the names for them; and

6. our final chart is:

$\begin{array}{lll}\text { Group } & \text { Meaning } & \text { Fillmore's Frame Feature } \\ \text { [ } & \text { come into possession } & +[-\mathrm{G}, \mathrm{O}, \mathrm{S}] \\ \text { II } & \text { inchoative } & +[-(\mathrm{E})(\mathrm{O})] \\ \text { III } & \text { movement } & +[-\mathrm{O}(\mathrm{G})(\mathrm{P})(\mathrm{I})(\mathrm{A})] \\ \text { IV } & \text { causative } & +\left[-\mathrm{A}, \mathrm{O}, \mathrm{G}_{\mathrm{St}}\right]\end{array}$

We hope this study may be a contribution to make the work of the teacher of English easier, when dealing with the verb get. 


\section{A P P E N D I X}

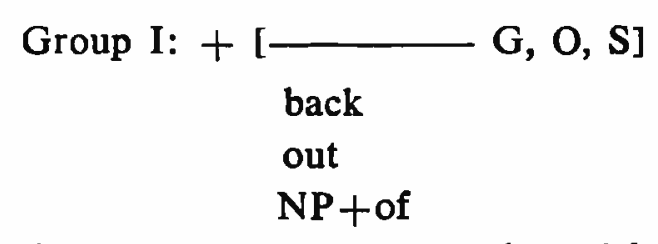

Group 111: prepositions and particles as Goal

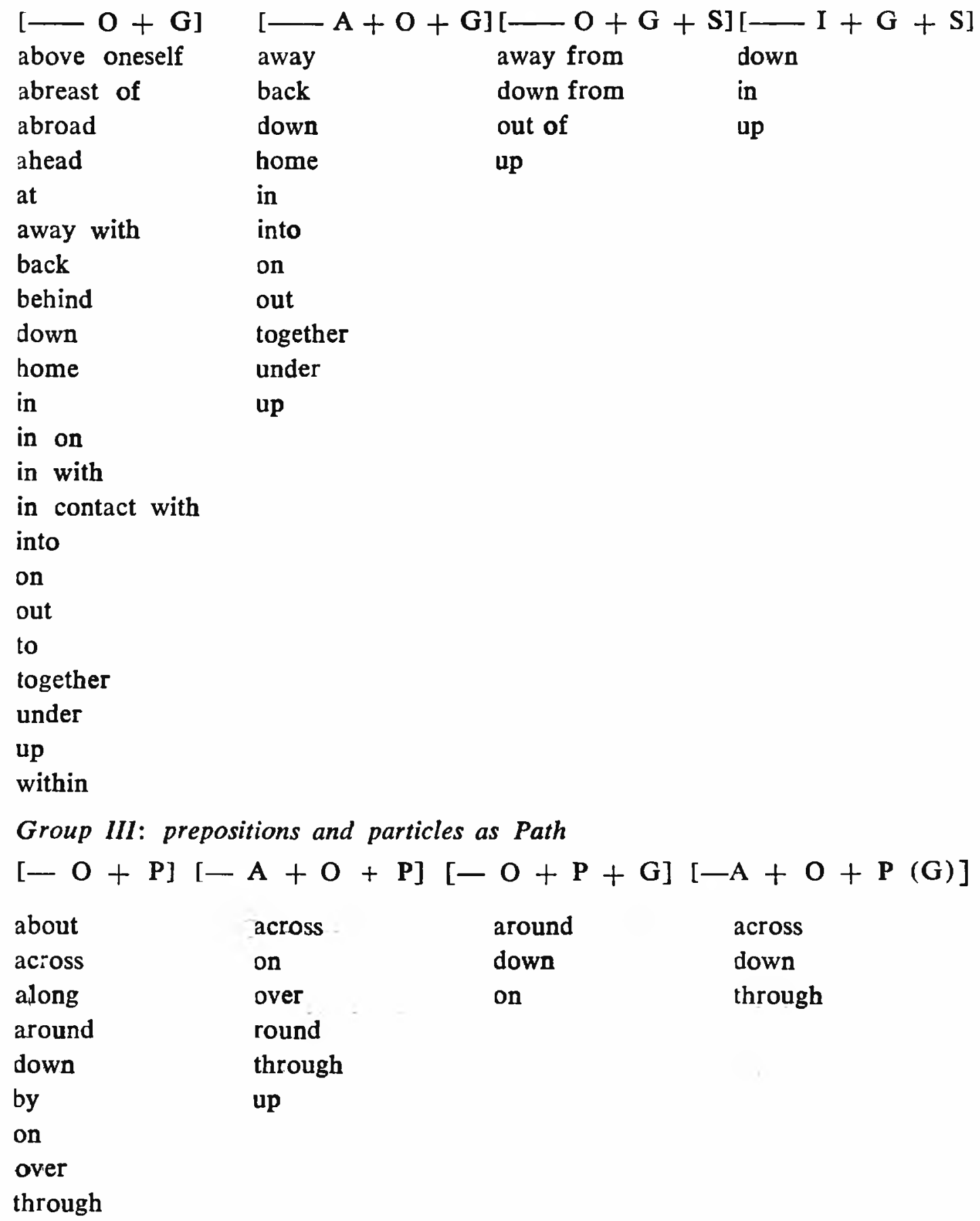




\section{A P P E N D I X}

Group III: prepositions and particles as Source

$\begin{array}{lll}{[-\mathrm{O}+\mathrm{S}+\mathrm{G}]} & {[-\mathrm{O}+\mathrm{S}]} & {[-\mathrm{A}+\mathrm{O}+\mathrm{S}]} \\ \text { back at } & \text { off } & \text { off } \\ \text { back into } & & \\ \text { back to } & & \\ \text { off } & \end{array}$

\section{BIBLIOGRAPHY}

CHRISTOPHERSEN, P \& A. O. Sandved - An Advanced English Grammar, MacMillan, London, 1969.

COPPERUD, Roy H. - Dicionário de Inglês Coloquial, a gíria contemporânea., Difel, São Paulo, (s. d.)

COWIE, A. P \& R. Mackin - Oxford Dictionary of Current Idiomatic English, Volume 1: Verbs with Prepositions \& Particles, Oxford University Press, London, 1975.

CROWELL, Thomas Lee Jr. - Index to Modern English, McGraw Hill, N. Y., 1964.

FILLMORE, Charles D. - "The Case for Case" in Emmon Bach \& Robert T. Harms (eds.) - Universals in Linguistic Theory, Holt, Rinehart \& Winston, Inc., 1968.

- "Some Problems for Case Grammar" in 22nd Annual Round Table Monograph Series on Language and Linguistics, Nr. 24 1971, p. 35-56.

FRASER, Bruce - "Some Remarks on the Verb-Particle Construction in English" in 17 th Annual Round Table, Monograph Series on Language and Linguistics, Nr. 19, 1966, p. 45-61.

FREIDIN, Robert - "The Analysis of Passives" in Language 51, Nr. 2, June 1975 , p. $384-405$.

GAMARSKI, Lea - Ocorrências de Reflexivo nas Construções Incoativas, tese de mestrado, PUCSP, 1974.

HASEGAWA, K. - "The Passive Construction in English" in Language 44, Nr. 2, June 1968, p. 230-243.

HEATON, J. B. \& J. P. Stocks - Overseas Students' Companion to English Studies, Longman, London, 1970.

HEATON, J. B. - Prepositions and Adverbial Particles, Longmans, London, 1969.

HOPPER, Vincent F. - 1001 Pitfalls in English Grammar, Spelling and Usage, Barron's Educational Series, Inc., N. Y., 1970.

JOHNSON, A. - Common English Proverbs, Longmans, London, 1973.

LAKOFF, George - Irregularity in Syntax, Holt, Rinehart \& Winston, Inc., N. Y., 1970 . 
MARCKWARDT, Albert H. - American English, Oxford, N. Y., 1958.

McMORDIE, W - English Idioms, Oxford Univeisity Press, London, 1972.

PALMER, F R. - A Linguistic Study of the English Verb, Longman, London, 1973.

- The English Verb, Longman, London, 1974.

PITTMAN, G. A. - Activating the use of prepositions, Longmans, London, 1966.

THOMSON, R. D. \& A. H. Irvine - Collins Everyday English Usage, Collins, London, 1968.

WARD, John Millington - British and American English, Longmans, London, 1965 .

WHITFORD, H. C. \& R. J. Dixon - Handook of American Idioms and Idiomatic Usage, Regents, N. Y 1973. 